\author{
Maciej Kochanowski
}

\title{
Rights of the Posted Workers - Directive 96/71/EC and the Evolution of Legislation Concerning Posted Workers ${ }^{1}$
}

\begin{abstract}
Introduction
The freedom to provide services and the freedom of movement for workers are the basic, an essential freedoms set out by the EU Treaties. They form - together with other freedoms - essential base for the Internal Market of the European Union. However, it should be noted that those two aspects of EU law can cause conflicts between employers and their workers. It can also be a cause of unfair competition between employers from different Member States - especially when the Member States have significantly different employment conditions. This can lead to social dumping or so called race to the bottom. In this article I shall describe the issues concerning the conflicts of the rights of the posted workers (a similar but separate category than freedom of movement of workers) with rights and interests of the employers. I shall also point out at the measures that have been taken so far by the European Union to improve effective protection and balance between those two aspects. For the better understanding of this issue, a very brief overview of both definitions will be given in this article.
\end{abstract}

\section{The Definition of the Freedom of Movement for Workers and Definition of Posted Workers}

The freedom of movement for workers is a particular aspect of freedom of movement of persons. Above all, its purpose is to ensure the protection of citizens of the European Union. ${ }^{2}$ This freedom, along with all EU Labour Law in general, is one of the most es-

1 The final version of the article was prepared in June 2017, therefore the newest developments of the topic are not included, as they would have to be addressed in a separate article.

2 L. Florek, Europejskie Prawo Pracy, Warszawa 2010, p. 46. 
sential measures of social politics of the European Union. The principle of the freedom of movement for workers was established chiefly by Article 45 of Treaty of Functioning of the European Union (formerly Articles 39 and 48) and by the Regulation No 1612/68 of the Council of 15 October 1968 on freedom of movement for workers within the Community (amended by the Regulation No 312/76 of 9 February 1976 and Regulation No 2434/92 of 27 July 1992). According to this regulation (Article 45 TFEU), freedom of the movement of workers shall be secured within the Union. In principle, it is ensured by the abolition of discrimination based on nationality between workers of the Member States. This applies to employment, remuneration and other conditions of work and employment. It consists of - above all - access to employment and equal treatment. Article 45 of Treaty of Functioning of the European Union states that this freedom is only given to workers. To ensure uniformity of this regulation, definition of a worker is to be understood in a way set out by the European Union Law and cannot be defined by any of the national law of Member States. ${ }^{3}$ As this definition is not expressly stated in any of $\mathrm{EU}$ acts, it is defined by the Jurisprudence. According to Judgments of the European Court of Justice (ECJ) the definition must be based on objective criteria. ${ }^{4}$ Those criteria establish that for a certain period of time a person performs services for and under the direction of another person in return for which he receives remuneration. Remuneration is an essential part of employment relationship - employment needs to have an economic aim. Low remuneration and short working hours, however, do not mean that such service cannot be regarded as employment relationship. ${ }^{5}$ It should be noted however, that Court of Justice has used slightly different terminology depending on the context. ${ }^{6}$

The protection provided by the freedom of movement for workers generally does not apply to the full extent to posted workers, who are mostly protected by the Directive 96/71/EC. ${ }^{7}$ The protection does not cover all areas - it is ensured only in matters expressly stated in the Directive 96/71/EC. For the purposes of this Directive, 'posted worker' means a worker who, for a limited period, carries out his or her work in the territory of a Member State other than the State in which he normally works. The employer must be an entity established in one Member State that posts workers to another

3 Judgment of the Court of Justice of the European Union of 19 March 1964 Mrs M.K.H Hoekstra (née Unger) v Bestuur der Bedrijfsvereniging voor Detailhandel en Ambachten (Administration of the Industrail Board for Retail Trades and Businesses, C-75-63.

4 Judgment of the Court of Justice of the European Union of 3 July 1986 Deborah Lawrie-Blum v. Land Baden Würtemberg, C-66/85.

5 Judgment of the Court of Justice of the European Union of 3 June 1986 R.H.Kempf v.Staatssecretaris van Justitie, C- 139/85.

6 Judgment of the Court of Justice of the European Union of 12 May 1998 María Martínez Sala v Freistaat Bayern, C-85/96, European Court reports 1998 Page I-02691; A.C.L. Davies, EU Labour Law, Oxford 2012, p. 174.

7 Directive 96/71/EC of the European Parliament and of the Council of 16 December 1996 concerning the posting of workers in the framework of the provision of services. 
Member State, whereas the worker is employed in the country where the employer is established. ${ }^{8}$ Whether a worker is a posted worker or a "normal" migrant worker has to be decided on a general basis, as a general assessment of all factual elements. The most important factor is the period of time of employment when the worker is providing work in another Member State 9 . In one of the judgments, the Court has ruled that an open - ended employment contract and fixed term contracts (when the date of finishing the undertaking was not specifically precised) shall be regarded as permanent employment. ${ }^{10}$ Although it is not clearly stated by any act, a period exceeding 24 months of employment is often regarded as permanent employment. ${ }^{11}$ The Directive 96/71 applies only if the undertakings take one of the following transnational measures mentioned in Article 1 of the Directive (post workers to the territory of a Member State on their account and under their direction; or post workers to an establishment or to an undertaking owned by the group in the territory of a Member State; or being a temporary employment undertaking or placement agency).

The posted workers form a specific category that has similar rights as the workers that migrate to other Member State (the obligations of the posted workers or their employers also vary - for example, the employers that provide services with posted workers are obliged to fulfill some specific obligations, as for instance providing workers with a certificate of posting ${ }^{12}$ ). It also means that the posted workers do not enjoy the right to equal treatment as the migrant workers that seek employment in another Member State.

The posted workers are only given a certain "core" of labor rights, consisting of a catalogue of working conditions and terms of employment. ${ }^{13}$ On the other hand, setting a fixed minimal pay and minimal conditions of work is a form of interference in the contractual relations. ${ }^{14}$ However, it seems to be necessary for securing the elemental need of the posted workers (especially on the international level). Such interference is also necessary in order to ensure the protection of the dignity of the worker. ${ }^{15}$

\section{A. Świątkowski, Prawo Pracy Unii Europejskiej, Warszawa 2015, p. 172.}

9 Ibidem, p. 170-171.

10 Judgment of the Court of Justice of the European Union of 30 November 1995 Reinhard Gebhard v Consiglio dell'Ordine degli Avvocati e Procuratori di Milano, C-55/94.

11 K. Jaśkowski, Meritum Prawo Pracy 2017, Warszawa 2017, p. 99.

12 A. Świątkowski, op. cit., p. 174.

13 Directorate - General for Internal Policies, Posting of workers directive current situation and challenges, 2016.

14 A. Sobczyk, Prawo pracy w świetle Konstytucji RP. Wybrane problemy i instytucje prawa pracy a konstytucyjne prawa i wolności cztowieka, Warszawa 2013, p. 35-36.

15 C. Dupré, La respect de la dignité humaine: principe essentiel du droit du travail, "Revenue de droit du Travail "2016, no. 11, p. 674-675. 
254 | Adam Mickiewicz University Law Review

\section{Definition of Freedom to Provide Services}

Freedom to provide services is another freedom established by the Community. It is also an essential part of the EU Community and it creates uniform social-economic conditions for ensuring the functioning of the EU market. ${ }^{16}$ The bases of this freedom are set out in Articles 56-62 TFEU and in the Directive 2006/123/EC of the European Parliament and of The Council of 12 December 2006 on services in the Internal Market. ${ }^{17}$ According to the provision of Article 56, restrictions to provide services within the Union shall be prohibited in respect of nationals of Member States who are established in a different Member State. The main aim of this freedom is to allow business entities (entities such as natural persons, legal persons, organizational entities not being legal persons, in which a statute vests legal capacity) to move from one Member State to another in order to provide services. Further, this freedom prohibits any unjustified limits to the free circulation of such services. In other words, the Treaties preclude the application of any national legislation which has the effect of making the provision of services between Member States more difficult than the provision of services exclusively within one Member State. ${ }^{18}$

Article 57 provides a very brief and general definition of services - services shall be considered to be 'services' within the meaning of the Treaties where they are normally provided for remuneration and when they are not governed by other freedoms (freedom of movement for goods, capital and persons). They should also have a cross-border and intangible nature. Generally they should be provided on temporary basis. ${ }^{19}$

The protection of workers and the protection of business entities (freedom to provide services) have different subjects of protection. It is hard to achieve the necessary balance between them, as the interests of workers and interests of employers are often in conflict.

It is a task of all Member States to comply with EU legislation, and not to create national legislation that could hinder that freedom in any way. Both legal and natural persons (and organizational entities not being legal persons, in which a statute vests legal capacity) can rely on these rules as they are directly effective.

\section{Directive 96/71/EC}

Directive 96/71/EC of the European Parliament and of the Council of 16 December 1996 concerning the posting of workers in the framework of the provision of services

16 M. Kożuch, Swoboda Świadczenia Ustug w Unii Europejskiej - System Prawa Unii Europejskiej, Warszawa 2011 p. XVII-1.

17 Official Journal of the European Union 27.12.2006 L 376/36.

18 Judgment of the Court of Justice of the European Union of of 28 April 1998 Jessica Safir v Skattemyndigheten i Dalarnas Län, formerly Skattemyndigheten i Kopparbergs Län, Case C-118/96.

19 J. Barcz, Prawo Gospodarcze Unii Europejskiej, Warszawa 2011, p. IV-25. 
(The EU Posted Workers Directive) concerns mostly the rights and treatment of posted workers, as well as the freedom to provide services given to the business entities.

The aim of this Directive is to ensure that posted workers provide work under the terms and conditions (only those terms and conditions expressly stated in the Directive - Article 3) imposed by the country where the work is carried out. The aim is also to promote the transnational provision of services while ensuring fair competition and measures guaranteeing respect for the rights of workers (point 5 of the preamble). In order to reach this aim, this Directive operates with overriding mandatory provisions - the norms that are applicable independently of the law applicable to the employment contract, unless the provisions of that country gives the better protection to those workers (Article 3(7)).

On one hand, the purpose of this regulation is to protect those Member States, where the service is carried out; on the other, Directive ensures the protection of the posted workers' rights. ${ }^{20}$ It is only natural that the Member States need to protect their own market from so called social dumping - a situation when a country less developed Member State can provide another Member State with workers having much lower salary expectations. As a consequence, this can lead to exclusion of the workers residing in the host country.

However, it should be noted that Directive 96/71/EC does not include any executive regulations. Several years after coming into force, many abuses committed by entrepreneurs were revealed. Some of the entrepreneurs had used to their advantage the differences in salary level in different Member States. ${ }^{21}$ As the division of the competences concerning the supervision of the entrepreneurs (whether they comply with regulations imposed by this Directive or not) could not be precisely determined, the EU institutions were not able to effectively protect the posted workers. The criticism has escalated in 2007/2008, when several cases concerning conflicts of rights of entrepreneurs with the rights of the posted workers had been heard by the European Court of Justice.

\section{Laval Un Partneri Ltd v Svenska Byggnadsarbetareförbundet C-341/05 22}

In the abovementioned case, the facts were as follows. A Latvian company (Laval Un Partneri Ltd) concluded a contract with Swedish government to renovate schools in Sweden (May - December 2004). The company was using Latvian workers. Their salary was significantly lower compared to Swedish workers. The minimum salary was not

20 P. Wąż, Delegowanie pracowników do innego Państwa Członkowskiego celem świadczenia ustug, Warszawa 2011, p. 3.

21 A. Świątkowski, op. cit., p. 171.

22 Judgment of the Court of Justice of the European Union of 18 December 2007 Laval Un Partneri Ltd v Svenska Byggnadsarbetareförbundet, C-341/05. 
fixed by Sweden by statutory law as it was regulated mostly by collective agreements. The Swedish Building Workers' Union (Svenska Byggnadsarbetareforbundet) negotiated with the Laval Ltd in order to encourage them to sign a collective agreement. That document aimed to ensure a higher level of the minimum salary for the Latvian workers, but also stated that the companies were obliged to pay $(1,5 \%$ of total gross wages for the Union, $0,8 \%$ to the insurance company and $5,9 \%$ for the purposes of insurance premiums). Finally, Laval Ltd refused to sign the agreement, which eventually led to a dispute between two parties. In response, collective actions against Laval (that had started already before negotiations) intensified, eventually leading to boycott of all Laval's sites in Sweden. The company was no longer able to carry out its activities in Sweden. Laval claimed that the blockade infringed its freedom to provide services. Laval also claimed for compensation against trade unions (other trade unions also participated in collective actions) for the damage suffered. The matter was referred to the ECJ by the Swedish court (preliminary ruling).

One of the questions posed to the ECJ concerned the right to force a foreign provider of services to sign a collective agreement (considering that no express provisions concerning the application of terms and conditions of employment in collective agreements were binding under Swedish law) and whether or not it is compatible with freedom to provide services.

According to Article 3 of Directive 96/71/EC of the European Parliament and of the Council of 16 December 1996 concerning the posting of workers in the framework of the provision of services, Member States shall guarantee posted workers terms and conditions provided in the Member States where the work is carried out (the terms and conditions set out by statutory law or by collective agreements - collective agreements could only apply to some economy sectors). This applies among other things to minimum rates of pay. Such rights shall not prevent application of terms and conditions of employment which are more favourable to workers.ECJ acknowledged that the right to take collective action for the protection of the workers of the host State against possible social dumping may constitute an overriding reason of public interest within the meaning of the caselaw of the Court which, in principle, justifies a restriction of one of the fundamental freedoms guaranteed by the Treaty.

Further, the Court of Justice held that undertakings established in other Member States would compete unfairly against undertakings of the host Member State in the framework of the transnational provision of services, if the level of social protection in the host Member State is higher. Despite the fact that a minimum wage had not been imposed by the Swedish Law (and had to be provided by the collective agreements), considering however that collective agreements were not in fact declared "universally applicable" the ECJ held that trade unions; not being bodies governed by public law, "could not avail themselves of that provision by citing grounds of public policy in order 
to maintain that collective action such as that at issue in the main proceedings complies with Community law".

It can be argued that this judgment led in fact to limiting rights of posted workers. In some way the judgment acknowledged that under the Directive 96/71/EC these workers were striped of the rights that had been granted to Swedish workers by the "non-universally" applicable collective agreements. Despite the fact that there was no unfair treatment of the posted workers that had been imposed by the statutory law itself, as a matter of fact, posted workers had not been considered as having the same rights as most Swedish workers. This case establishes a change to interpretation of Directive 96/71/EC by saying that the Directive limits the level of protection guaranteed to posted workers. Neither the host Member State nor the social partners can ask for more favourable conditions going beyond the mandatory rules for minimum protection set forth in the Directive. ${ }^{23}$

\section{Similar Cases "Laval quartet"}

Laval case forms together with: Viking ${ }^{24}$, Commision v. Luxemburg ${ }^{25}$, Rüffert $^{26}$ so called "Laval quartet". Those cases have determined the division of the competences of the Member States regarding regulation of the rights of posted workers. ${ }^{27}$

In those judgments the ECJ ruled that it is not in principle prohibited to organize collective agreements in order to induce a company to enter into a collective agreement. However they may be considered as a restriction on the freedom of services and the freedom of establishment. The protection of those rights (the freedom to provide services and the freedom of establishment as well as rights of posted workers) is not uniform and is dependent on the circumstances and the nature of a claim. ${ }^{28}$

The abovementioned cases also clarify that the freedom to provide services may in fact impose restrictions on the right to collective action of the posted workers. This applies

23 A. Bücker, W. Warneck, Viking, Laval, Rüffert: Consequences and policy perspectives, Brussels 2010, p. 10.

24 Judgment of the Court of Justice of the European Union of 11 December 2007 International Transport Workers' Federation and Finnish Seamen's Union v Viking Line ABP and OÜ Viking Line Eesti Case, C-438/05.

25 Judgment of the Court of Justice of the European Union of 19 June 2008 Commission of the European Communities v Grand Duchy of Luxemburg Case, C-319/06.

26 Judgment of the Court of Justice of the European Union of 3 April 2008 Dirk Rüffert v Land Niedersachsen Case, C-346/06.

27 A. Świątkowski, Kwartet Laval w prawie pracy, Warszawa 2010, p. 34.

28 Directorate - General for Internal Policies, The impact of the ECJ judgments on Viking, Laval Rüfert, Luxembourg on the practice of collective bragaining and the effectiveness of social action, 2010, p. 6-7. 
in particular to situations when the actions are not aimed at regulating the conditions of employment of its own members.

Those judgments influenced mostly the legislation of those Member States (countries like Sweden or Denmark) whose labour law and employment conditions are mostly based on the autonomous collective bargaining model. The collective bargaining model means that it is the responsibility of the trade unions to supervise and protect employers in the country (posted workers included), especially in matters of wages. Such system cannot function properly without the occasional necessity of starting a collective action. ${ }^{29}$

Those cases also clarify, that the Directive 96/71/EC outlines the maximum level of protection for posted workers, stating that no collective agreement may, specify a higher level of protection. On the other hand, review of some cases show, that regulations of the Member States concerning posted workers, led in some cases to restrictions of the freedom to provide services. ${ }^{30}$ The problem of the method of calculating the elements that could be regarded as minimum rates of pay is not discussed closer in this article; it has been reviewed by the Court of Justice, also in recent cases. ${ }^{31}$

\section{Evolution of the Legislation}

The fact that some differences of the law systems of Member States can hinder application of equal treatment of the workers is not the sole problem concerning the protection of rights of posted workers. Another issue is the fact that Member States do not cooperate and exchange detailed information concerning the terms and conditions of employment. A level of understanding of such terms by both Member States and parties to the employment relation is essential to prevent disputes between themBearing these facts in mind, after detecting a possible loophole in the protection of the workers under $\mathrm{Di}$ -

29 Directorate - General for Internal Policies, The impact of the ECJ judgments on Viking, Laval Rüffert, Luxembourg on the practice of collective bragaining and the effectiveness of social acton, 2010, p. $7-8$.

30 Judgment of the Court of Justice of the European Union of 14 April 2005, Commission of the European Communities v Federal Republic of Germany Case C-341/02; Judgment of the Court of Justice of the European Union 19 January 2006 Commission of the European Communities v Federal Republic of Germany Case, C-244/04; Judgment of the Court of Justice of the European Union of 24 January 2002 Portugaia Construções Ld d $^{\text {a }}$ (Preliminary ruling) C-164/99,; R. Stefanicki, Ograniczenia swobodnego przeptywu ustug (kapitatu) usprawiedliwione względami interesu publicznego w świetle orzecznictwa europejskiego trybunatu sprawiedliwości, „Problemy Współczesnego Prawa Międzynarodowego, Europejskiego i Porównawczego”, vol. III, A.D. MMV 2005, p. 61.

31 Judgment of the European Court of Justice of 12 February 2015 Säbköalojen ammattiliitto ry v Elektrobudowa Spolka Akcyjna, C-396/13, Official Journal of the European Union C 118, 13.4.2015, p. 6-7. 
rective 96/71/EC, Commission in its Recommendation of 3rd April 2008 on enhanced administrative cooperation in the context of the posting workers in the framework of the provision services (COM(2006) 159 Final) drew attention of the Member States to the fact that closer cooperation might be necessary. The Commission indicated also that the Member States should actively participate in a systematic and formal process of identification and exchange of good practices in the field of posting of workers through any forum of cooperation established by the Commission. ${ }^{32}$ The abovementioned Recommendation, as well as the Commission Decision set out the guidelines in matters concerning compliance with the provisions of the Directive 96/71/EC and supervising the entrepreneurs. As a consequence, a group of experts was set up ("Committee of Experts on Posting of Workers") in order to: promote exchange of information, examine issues regarding implementation and application of the Directive, as well as examine the possibilities to increase effective compliance with rights of migrant workers. Eventually, a strategy concerning single market has been issued. ${ }^{33}$ The next step was proposing a new directive - Directive 2014/67/EC on the enforcement of Directive 96/71/EC. ${ }^{34}$

\section{Directive 2014/67/EU}

Directive 2014/67/EU aims to establish a common framework of a set of appropriate provisions, measures and control mechanisms necessary for the better application and enforcement of Directive 96/71/EC (Article 1 of Directive 2014/67/EU). Under the Directive, the Member States are obliged to designate one or more competent authorities, which may include the liaison office. The directive also sets out precise criteria (Article 4) for the assessment of all factual elements concerning posted workers (failure to satisfy one or more of the factual elements set out in paragraphs shall not automatically preclude a situation from being characterized as one of posting - it does not form an exhaustive enumeration) - the elements of the definition of a posted worker aims also to eliminate the problem of fictional posting. ${ }^{35}$

Under the Directive 2014/67/EU, the Member States are obliged to cooperate, share the necessary information concerning terms and conditions of employment (especially

32 2009/17/EC: Commission Decision of 19 December 2008 setting up the Committee of Experts on Posting of Workers.

33 M. Monti, A new Strategy for The Single Market: At the Service of Europe's Econommy and Society. Report to the President of the European Commission Jose Maunel Barroso, Milano 2010.

34 Directive 2014/67/EU of the European Parliament and of the Council of 15 May 2014 on the enforcement of Directive 96/71/EC concerning the posting of workers in the framework of the provision of services and amending Regulation (EU) no. 1024/2012 on administrative cooperation through the Internal Market Information System.

35 P. Wąż, Polska ustawa o delegowaniu pracowników „Monitor Prawa Pracy” 2016, no. 10, p. 511. 
those referred in Article 3 of Directive 96/71/EC), provide each other with mutual assistance and take the all appropriate measures to ensure the compliance and application of the terms and conditions of employment referred to in Article 3 of Directive 96/71/ EC. Member States shall also provide the posted workers with the possibility of lodging complaints against their employers directly, as well as commence judicial or administrative proceedings (Article 11). Member States are also obliged to impose penalties applicable in the event of infringements of national provisions adopted pursuant to this Directive.

According to Article 23 of Directive 2014/67/EU, Member States were obliged to implement the provisions of this directive by 18 June 2016 (no later than 18 June 2019, a rapport of the Commission on its application and implementation to the European Parliament shall be issued). Some Member States (Poland) ${ }^{36}$ decided to place most of the norms concerning the posted workers from the Directive 2014/67/EU and Directive 96/71/EC in a separate statue, others decided to change the existing regulations.

The possible outcome and application of Directive 2014/67/EU is hard to predict as the Member States as it has only been few month since the deadline for implementation expired. It is also questionable whether it will provide and maintain the balance between the rights of posted workers and the freedom to provide services. It can be noted however, that the new Directive consists of rather general provisions that may not be sufficient to ensure reasonable level of protection to the posted workers. That is a reason why the new Directive 2014/67/EU has been criticized by some Member States and the legal doctrine. Some say that will not completely stop problems with implementing the effective protection of posted workers. It may also lead to other problems in the future ${ }^{37}$ (such as differences between the understanding posted workers in the Directive 2014/67 and Regulation 883/2004 ${ }^{38}$ ).

On the other hand this Directive has been criticized during the legislative procedure as being too restrictive for employers leading in fact to discrimination against some groups of employers. ${ }^{39}$

\section{Proposal for Amendment of Directive 96/71/EC}

Some Member States (Austria, Belgium, France, Germany, Luxembourg, the Netherlands and Sweden) issued a petition claiming for a modernisation of the Posting of Workers Directive that would establish the principle of 'equal pay for equal work in the same place'. Those Member States argued that remuneration, applicable to posted work-

36 Dz.U. 2016 item 868.

37 F. Pennings, G.Vonk, Research Handbook on European Social Security Law, 2015, p. 368-369.

38 Regulation (EC) no. 883/2004 of the European Parliament and of the Council of 29 April 2004 on the coordination of social security systems.

39 Letter of Polish Chamber of Commerce dated of 26 March 2014. 
ers should be amended and widened. Bearing in mind those opinions, a proposal for amendment of Directive 96/71 has been issued. ${ }^{40}$

Its aim is to address unfair practices (that are still an issue) and to promote the principle that the same work at the same place should be remunerated in the same manner. The initiative focuses on issues which were not addressed by Directive 96/71/EC and it does not address any issue regulated by Directive 2014/67/EC.

Among the proposed changes is the provision making collective agreements universally applicable within the meaning of Article 3(8) (in all sectors of the economy irrespective of the activities). Another significant change replaces the term "minimum rates of pay" with the "remuneration" (as opposed to the term 'rates of pay', term "remuneration" includes other financial benefits from employment relation, such as complementary benefits). The new proposal also aims to impose on Member States an obligation to publish information on the constituent elements of remuneration. Also a provision concerning applicable labour law is added (when the anticipated or the effective duration of posting exceeds twenty-four months, the Member State to whose territory a worker is posted shall be deemed to be the country in which his or her work is habitually carried out). Other changes concerns the conditions applicable to workers hired out by a temporary agency and provisions which deal with situations of subcontracting chains.

In response to the proposal, number of Member States (Bulgaria, Czech Republic, Estonia, Hungary, Lithuania, Latvia, Poland, Slovakia and Romania) have argued that a review of Directive $96 / 71 / \mathrm{EC}$ is premature and should be postponed after the full implementation of the Directive 2014/67 and its assessment. ${ }^{41}$ These Member States also stated that the principle of equal pay for equal work in the same place may be incompatible with the single market, creating in fact a restriction on freedom to provide services for entrepreneurs from some Member States (lower rates of pay were deemed by them as legitimate element of competitive advantage). Some entrepreneurial organization have also stated that such amendments may significantly increase the costs of posting worker, making it unprofitable and thus creating an effective restriction on freedom to provide services.

\section{Conclusion}

European Labour Law concerning matters such as minimal conditions of work and minimal pay is evolving rapidly. Bearing in mind that altogether, in 2014 there were over

40 Proposal for a Directive of the European Parliament and of the Council amending Directive 96/71/EC of The European Parliament and of the Council of 16 December 1996 concerning the posting of workers in the framework of the provision of services.

41 Ibidem. 
1.9 million postings in the EU (which is an upward trend ${ }^{42}$ ), it should be noted that possible changes to the legislation concerning posted workers will have a significant influence on the Internal Market, as well as on the particular Member States and further on workers and employers. The top sending Member States in 2011 were Poland, Germany and France, while top receiving Member States were Germany, France and Belgium. These numbers do not mean however, that future legislation will have the strongest impact only on those countries.

The balance of the freedom to provide services and the rights of posted workers somehow resembles the conflict of interests between particular Member States - Member States with lower rates of pay tend to support the idea of reinforcing the freedom to provide services, while more economically developed Member States (with higher rates of pay and level of remuneration) try to prevent locking out entrepreneurs established in their territory thus supporting idea of further widening the protection of posted workers by imposing higher labor standards for protectionist reasons. ${ }^{43}$ The raising influence of the private entities (entities having influence almost as significant as a country) might also pose another threat to the compromise in that matter. It should be noted that the protection of the posted workers seems to become strongly reinforced by the newest EU legislation and its proposed amendments. However, as the economic and social policies of all Member States are at stake, agreement on this matter will not be a simple task, rendering determination of proper balance of those two aspects of European Law a difficult matter.

\section{Literature}

Barcz J. , Prawo Gospodarcze Unii Europejskiej, Warszawa 2011.

Breining-Kaufmann C., Globalisation and Labour Rights. The Conflict between Core Labour Rights and International Economical Law, Oxford - Portland 2007.

Bücker A., Warneck W., Viking, Laval, Rüffert: Consequences and policy perspectives, Brussels 2010 .

Davies A. C. L., EU Labour Law, Oxford 2012.

Dupré C., La respect de la dignité humaine: principe essentiel du droit du travail „Revenue de droit du Travail"11/2016.

Florek L., Europejskie Prawo Pracy, Warszawa 2010.

Jaśkowski K., Meritum Prawo Pracy 2017, Warszawa 2017.

Kożuch M., Swoboda Świadczenia Ustug w Unii Europejskiej - System Prawa Unii Europejskiej, Warszawa 2011.

42 Ibidem.

43 C. Breining-Kaufmann, Globalisation and Labour Rights. The Conflict between Core Labour Rights and International Economical Law, Oxford Portland 2007, pp. 87-88. 
Monti M., A new Strategy for The Single Market: At the Service of Europe's Econommy and Society. Report to the President of the European Commission Jose Maunel BarrosoMilano 2010.

Pennings F., Vonk G., Research Handbook on European Social Security Law, 2015.

Stefanicki R., Ograniczenia swobodnego przeptywu ustug (kapitatu) usprawiedliwione względami interesu publicznego w świetle orzecznictwa europejskiego trybunatu sprawiedliwości „Problemy Współczesnego Prawa Międzynarodowego, Europejskiego i Porównawczego" 2005, vol. III.

Sobczyk A., Prawo pracy w świetle Konstytucji RP, in: Wybrane problemy i instytucje prawa pracy a konstytucyjne prawa i wolności cztowieka, Warszawa 2013.

Świątkowski A., Prawo Pracy Unii Europejskiej, Warszawa 2015.

Świątkowski A., Kwartet Laval w prawie pracy, „Państwo i Prawo” 2010, no. 12.

Wąż P., Delegowanie pracowników do innego Państwa Cztonkowskiego celem świadczenia ustug, Warszawa 2011.

Wąż P., Polska ustawa o delegowaniu pracowników „Monitor Prawa Pracy” 2016, no. 10.

Directorate - General for Internal Policies, The impact of the ECJ judgments on Viking, Laval Rüffert, Luxembourg on the practice of collective bargaining and the effectiveness of social action, 2010.

Directorate - General for Internal Policies, Posting of workers directive current situation and challenges, 2016.

\section{SUMMARY}

\section{Rights of the Posted Workers - Directive 96/71/EC and the Evolution of Legislation Concerning Posted Workers}

The aim of the study is to analyse the conflict of rights of posted workers with entrepreneurs' freedom to provide services in posting of workers Directive 96/71/EC and the enforcement Directive 2014/67/EC. The author presents the key issues of the conflict, as well as its evolution in EU legislation and in European Court of Justice judgments.

Keywords: posted workers, freedom to provide services, Directive 96/71/EC, Directive 2014/67/EC, Treaty on the Functioning of European Union, European Labour Law, European Union Laws

Maciej Kochanowski, Adam Mickiewicz University in Poznań, Faculty of Law and Administration, Niepodległosci 53, 61-714 Poznań, Republic of Poland, e-mail: maciej.kochanowski@amu.edu.pl. 
